\title{
Entrepreneurship in the Renewable Energy Sector of Bangladesh: A Conceptual Analysis for Exploring Opportunity and Challenge
}

\author{
Rubaya Ismat Shithila Nasrin Sultana Fahad Rashid Tasdeed Hossain Tasin \\ Shadman Fahim Md. Saifullah Md.Abdullahil Kafi Protiva Mohiuddin \\ The School of Business and Economics, United International University, Bangladesh
}

\begin{abstract}
Bangladesh is endowed with ample supply of renewable sources of energy. By acknowledging the potential of renewable energy resources, Bangladesh could possibly meet its unprecedented energy demand, thus enhancing electricity accessibility to all and increasing energy security through their progression. A significant number of studies demonstrated the socioeconomic impact of the renewable energy especially in Bangladesh. According to these studies, it is realized that the entrepreneurial perspective of renewable energy is missing, with the exception of a few studies on innovation theory, social entrepreneurship, and micro-finance. The endeavor of this article is to argue that the renewable energy is an opportunity to slow environmental degradation opening a new perspective of the research agenda in entrepreneurship. In addition to that, it is hoped that this article contributes to the connection of entrepreneurial perspective, its opportunities and challenges, with renewable energy in the emerging markets in Bangladesh. This work allows introducing Bangladesh as an emerging context of entrepreneurship in renewable energy sectors of Bangladesh.
\end{abstract}

Keywords: Renewable Energy, Entrepreneurship, Scope, Challenge, Bangladesh

\section{Introduction}

Deployment of renewable energy and energy efficiency including technological diversification would result in significant energy security and economic benefits in Bangladesh. In this regard the government of Bangladesh has planned to generate $20 \%$ of total generation by nuclear, renewable and cross border by 2030 out of 40,000 MW total expected generations. Renewable energy (RE) technologies will result in reducing dependency on fossil fuel to a sustainable level and it will ultimately minimize load shed, further expansion of national grid at remote rural areas in Bangladesh. In this regard the Government of Bangladesh has planned to generate $5 \%$ of generation and subsequently $10 \%$ by 2020 from renewable sources. The average cost of power generation in Bangladesh is approximately BDT. 6.02/KWh and diesel based generation is BDT. $15.80 / \mathrm{KWh}$, the cost of renewable energy is appears to be pricey with comparison to conventional energy but the difference between conventional and RE is gradually decreasing due to availability of efficient RE technologies. Gradual expansion of RE in Bangladesh is getting popularity as the natural resources e.g. gas is depleting with an approximate projection of declining time around 2017 as indicated in Power System Master Plan 2010 (PSMP 2010).

Bangladesh has also created Sustainable and Renewable Energy Development Authority (SREDA) to implement and disseminate the idea and efficient technology including utilization of Read rural and urban areas of Bangladesh through scores of program. The power division has published programs, action plans and subsequent master plan in this regard to promote the adoption of RE and energy efficiency programs for demand side management. The government, however, is committed to provide electricity to all citizens by 2021 at a reasonable and affordable price. So, this program is placing as priority on developing RE resources considering the development of off grid electrification program at all level as $40 \%$ of the people of the country live in remote areas which are far away from existing grid line and sometime isolated from the main land (Power Division, 2014).

Hence, considerable attention has been paid to this tremendous energetic transition and its impact on economic activities around the world. Researchers have conducted many empirical studies to show the socioeconomic impact of these renewable energy projects using several methodologies, concepts and theories. Engelken et al. (2016: 798) show that the concepts used in the literature belong to economics and business research. Based on theories/concepts listed on that literature review (Engelken et al., 2016: 801), it is realized that the entrepreneurial perspective of renewable energy is missing with the exception of a few studies on innovation theory, social entrepreneurship, and microfinance. Furthermore, York and Venkataraman (2010: 450) argue that while there has been recent literature on how large companies can gain competitive advantage through 'greening', little has been produced on the entrepreneurial role in correcting environmental degradation. From an entrepreneurship perspective, environmental problems should be viewed as an opportunity for new value creation.

Although researchers in entrepreneurship have made considerable efforts in recognizing the role of the concept of opportunity (Shane, 2000), little existing research has been made in the discussion of entrepreneurial opportunities and challenges for renewable energy. According to Venkataraman (2010: 122), "one of the most neglected questions in the entrepreneurship literature is where opportunities to create goods and services in the 
future come from". One of the most important weaknesses in the entrepreneurship literature is the lack of studies on the connection of entrepreneurial perspective, opportunities and its challenges, with renewable energy business in the emerging market countries. Consequently, sustainability is viewed as an integral part of the entrepreneurship domain. As recently noted by Cohen and Winn, (2007), sustainable entrepreneurship is still a new field of research and it is in its infancy. In this extent, we strongly believe that entrepreneurship could have a positive impact on reducing environmental degradation through entrepreneurial action (Dean et McMullen, 2007).

In addition to that, Engel ken et al. (2016: 799) demonstrate, in their review on comparing drivers, barriers, and opportunities of business models for renewable energy, that academic researchers in the industrialized world do more research than in developing countries. However, Bangladesh is not among the developing countries analyzed by researchers despite the remarkably ambitious strategy Bangladesh has launched to promote renewable energy. In order to fill this gap, it is aim in this article to investigate the sources of entrepreneurial opportunities related to renewable energy.

\section{Renewable Energy Resources in Bangladesh}

Fossil energy resources in Bangladesh consist primarily of natural gas. The supply of domestic oil is considered negligible. Several small deposits of coal exist in the northeastern region of the country, but these consist of peat, with low caloric value and very deep bituminous coal that will be quite expensive to extract. Only $15 \%$ of the total population has access to electricity. In 1990 only $2.2 \%$ of total households had piped natural gas connections for cooking and only 3.9\% of total households used kerosene for cooking. This is by no means an encouraging scenario. Per capita consumption of commercial energy and electricity in Bangladesh is one of the lowest among the developing countries. In 1990, more than $73 \%$ of total final energy consumption was met by different type of biomass fuels, for example agricultural residues, wood fuels, animal dung, etc (Ahammed, F. and Taufiq, D.A, 2015).

The rural and remote sector of the Bangladesh economy is characterized by an abundance of open and disguised unemployment, high man-land ratio, alarmingly large numbers of landless farmers, extremely inadequate economic and social facilities, low standard of living and a general environment of poverty and deprivation. Larger energy supplies and more efficient energy use are therefore necessary to meet the basic needs of a growing population. It will consequently be necessary to include all sources of renewable energy and to use these in an efficient converted form for the people's benefit. Primarily this will be done in remote inaccessible unelectrified areas in a stand-alone system where grid expansion is expensive. This energy conversion will reduce pressure on the national power demand. This will not only save excessive grid expansion costs but will also be environmentally friendly (Barua, C.D et al., 2016).

Gradually, renewable energy and its different energy conversion technologies have become economically viable, capable of competing with fossil-fuelled technologies in the energy market. The size and economic potential of the renewable energy resources in Bangladesh are yet to be determined and the capacity of renewable energy development is presently low. Although investment costs of renewables are generally higher compared to fossil fuel alternatives, this option becomes economically viable when all externalities, e.g. environmental cost, health hazards etc. and lower operating costs are taken into consideration (Khan, Iqbal \& Mahboob, 2014).

\section{Solar Energy}

Bangladesh is located between 20.30 - 26.38 degrees north latitude and $88.04-92.44$ degrees east, which is an ideal location for using solar energy. Here, the daily average solar radiation varies between 4 to $6.5 \mathrm{kWh}$ per square meter (Islam, 2015).A maximum amount of radiation is available during the months of March and April while the minimum amount is available during December and January. The energy from sunlight reaching the earth is a huge potential that can be exploited and used for generating electricity. Of the number of available technologies, solar photovoltaic (PV) is the most promising. PV technology converts sunlight into direct current (DC) electricity. When light falls onto the active surface of the solar cell, electrons are energized and a potential difference is established, which drives a current through an external load. The major issue facing PV technology is cost, despite the fact that the cost of PV has fallen in several orders of magnitude and its efficiency has improved. Solar PV is becoming more and more popular due to high modularity, no requirement for additional resources, no moving parts, and only low maintenance is needed Over the last two decades, the cost of manufacturing and installing solar PV systems has decreased by about $20 \%$ for every doubling of installed capacity (Brown \& Hendry, 2009). The solar industry has grown at a rate of 35\% per year over the last ten years (British Petroleum website, 2011).

Infrastructure Development Company Limited (IDCOL) has supported NGOs in installing solar home systems (SHSs) and a total of 801,358 SHSs having capacity of about 36.5 MW have been installed up to January 2011 (Renewable energy projects, 2011). The Bangladesh Power Development Board (BPDB) has also 
implemented an excellent Solar PV electrification project in the Chittagong hill tracts region. Solar PV electrification has emerged as the most appropriate technological option for electrifying these areas (Renewable Energy Information Network, 2011).

\section{Wind Energy}

In Bangladesh's coastal areas there are some islands and inlands where wind energy can play a very important role in the country's economic development. The energy from continuously blowing wind can be captured using wind turbines that convert kinetic energy from wind into mechanical energy and then into electrical energy. Electricity generated by wind turbines can be fed to the central grid or be locally consumed using small standalone wind turbines. Gradually, generation of electricity from wind energy is proving to be very promising where speed and wind power density is sufficiently high (Mondal, 2010). Wind power generating capacity growth accelerated to $31 \%$ in 2009 throughout the whole world, with capacity increasing by a record $38 \mathrm{GW}$ to reach $160 \mathrm{GW}$ by the end of 2009 . Wind turbines for grid-connected systems are the most highly demanded on the market and the rate of capacity growth was 28\% per year between 1999 and 2009 (British Petroleumwebsite, 2011).

The BPDB installed a 160-foot tower at the Muhuri Dam site in the Feni district in May 2003. Two high resolution anemometers were installed on this tower, one anemometer at 80 feet and the other at a height of 160 feet. One wind vane was installed at 80 feet height. The average wind speed, up to now, at the Muhuri Damareas is found to be $6.50 \mathrm{~m} / \mathrm{s}$ and the wind power density varies from 100 to $250 \mathrm{Watt} / \mathrm{m} 2$ in the coastal regions of Bangladesh (Kaiser, Rahman, Rahman \& Sharna, 2006). For grid-connected wind turbines to be financially viable, the required annual average wind speed must be $6 \mathrm{~m} / \mathrm{s}$. The wind speeds are encouraging for the grid connected wind energy projects at Muhuri Dam in Feni (Renewable Energy information Network, 2011). This site is large enough for the larger wind energy projects.

The BPDB also implemented a $1000 \mathrm{~kW}$ capacity wind battery hybrid power project on Kutubdia Island (Bay of Bengal) in the Cox's Bazar district. Under this project, a total of $5020 \mathrm{~kW}$ capacity stand-alone wind turbines were installed. The total capacityof all the wind turbines is $1 \mathrm{MW}$. The wind turbines producing electricity is being stored in a battery bank. WBHPP officially began on March 30, 2008. In another project, BPDB implemented a $0.90 \mathrm{MW}$ capacity grid-connected wind energy (GCWE) at the Muhuri Dam area in Feni in 2004. This installation involved the commissioning and erection of 4 units of $225 \mathrm{~kW}$ GCWE turbines and these were completed in 2004. This represented the first ever GCWE project in Bangladesh. Thus generating electricity from wind in the coastal areas can be transmitted to other regions of the country through high voltage transmission lines (Renewable Energy Information Network, 2011). Very little operation and maintenance will be required during the whole life time of wind turbines and no fuel will be required for generating electricity from wind.

\section{Biomass and Biogas}

Biomass is the most significant energy source in Bangladesh which accounts for $70 \%$ of the total final energy consumption (Azad, 2011). This technology can be disseminated on a larger scale for generating electricity. Worldwide, biomass provides basic energy requirements for rural households' cooking and heating in developing countries. Biomass covers all kinds of organic matter from fuel wood to marine vegetation. Energy generation using biomass offers a promising solution toenvironmental problem by reducing the emission of common greenhouse gases. Several technologies exist for converting biomass into energy such as heat energy and electrical energy. Two widespread technologies are direct combustion and gasification. Direct combustion involves the oxidation of biomass with excess air, producing hot flue gases which in turn produce steam, which is used to generate electricity (Renewable Energy Technology Characterizations, 2013). Gasification involves conversion of biomass to produce a medium or low calorific gas. The obtained gas is then used as a fuel in combined cycle power generation plants. Being produced in combined cycle power plants, electricity from this technology is more efficient and more competitive than that from a steam turbine. Biogas mainly from animal and municipal wastes constitutes a promising renewable energy source for Bangladesh. It has the potential to harness basic biogas technology for cooking and rural and peri-urban electrification, so that electricity during periods of power shortfalls is still able to be provided.

In Bangladesh, Infrastructure Development Company Limited (IDCOL) financed a $250 \mathrm{~kW}$ biomass-based power plant at Kapasia, Gazipur. The plant uses locally available agricultural residues, i.e. rice husks as fuel for power generation. Being located in an unelectrified area, the plant is expected to supply environmentally friendly grid quality power to 300 households and commercial entities in that area (IDCOL, 2011). There are three million potential households with adequate cattle or poultry. In Bangladesh biogas is used mainly for cooking. From 1971 to October2009 about 41000 biogas plants were constructed by various NGOs under the national domestic biogas and manure programme (NDBMP) run by IDCOL, the sustainable energy for development (SED) program using German technical cooperation (GTZ), and other government organizations. These included 
for example, the Local Government Engineering Department (LGED), and the Bangladesh Council of Scientific and Industrial Research (BCSIR) (Islam, 2009).

\section{Hydro Energy}

Kinetic energy from flowing or falling water is exploited in hydropower plants to generate electricity. Hydropower plants are classified into two categories: 1) large6hydropower plants (>10 MW), usually with reservoirs, that cannot only produce electrical energy Continuously, but also are able to adjust their output according to electricity demand; and 2$)$ small hydropower plants $(<10 \mathrm{MW})$ that are less flexible with respect to load or demand fluctuation due to their dependence on the water resource (Mondal , 2010). Hydropower technologies are mature and widely available.

In Bangladesh about 1.4 trillion cubic meters $\left(\mathrm{m}^{3}\right)$ of water flows through the country in an average year. The country's major rivers have a high rate of water flow lasting for approximately 5 to 6 months during the monsoon season, which is substantially reduced in the winter season. More than $90 \%$ of Bangladesh's rivers originate outside the country, due to which proper planning of water resources is difficult without neighboring countries' cooperation. Downstream water sharing with India is a highly contentious issue for Bangladesh. The annual average rainfall is about $2,300 \mathrm{~mm}$, which varies from $1,200 \mathrm{~mm}$ in the north-west to $5,800 \mathrm{~mm}$ in the north-east. Most of the rainfall (about 80\%) occurs from May/June to September/October (Azad, 2011). At present only $230 \mathrm{MW}$ of hydro power is utilized in Karnaphuli, Rangamati hydro station, which is the only hydro-electric power plant operated by BPDB (Moury\& Ahshan, 2009). Microhydro and minihydro technologies have limited potential in Bangladesh, with the exception of Chittagong and the Chittagong hill tracts. Hydropower assessments have identified some possible sites from $10 \mathrm{~kW}$ to $5 \mathrm{MW}$ but no appreciable capacity has yet been installed (Renewable Energy Policy of Bangladesh, 2008).

\section{The Challenge of Entrepreneurship in Renewable Energy Sector in Bangladesh}

During the last decades, entrepreneurship and renewable energy research have been developed independently (Gabriel, 2016). Academics and practitioners in entrepreneurship theory have identified several keys that depict the entrepreneurial ecosystem. This concept includes all variables related to entrepreneurial action. Researchers of this work argue that these factors such as access to formal finance and credit, lack of investor protection, the provision of effectiveness of government regulations and incentive programs, political stability, access to information or education on how to start a new business, etc, influence strongly the entrepreneur's ability to recognize and exploit entrepreneurial opportunities. Institutional constraints and financial challenges are the most important barriers in Bangladesh. These results confirm what we can realize in Global Entrepreneurship Monitor's reports about entrepreneurship in developing countries. While some papers concentrate their thought on the lack of R\&D transfer and the lack of access to information and education on creating new ventures (Urban, 2013), others consider infrastructure constraints and lack of policy, legislative and tax incentives, property rights, etc, (Stel, 2013) as big challenges facing entrepreneurship in developing countries.

According to the literature reviewed by Gabriel (2016: 366), renewable energy challenges and those of entrepreneurship are the same in developing countries like Bangladesh. These challenges include what we can consider as the most common barriers to promote entrepreneurship in the RE field. The access to institutional and regulated finance is a key issue. Governments have to play the role of a facilitator in order to enhance international private sector involvement in RE. This does not mean that government in Bangladesh does not invest directly in that sector. Experiences in some European countries, the German experience, for instance, could be adopted for overcoming this challenge. Therefore, experiences in joint public-private or public-private partnership-type developed in emerging economies like China, India, Tanzaniaor South Africa (Martinot, 2001) may be more important to consider for implementation in the developing context.

In emerging countries like Bangladesh, the inabilities to achieve economies of scale influence negatively the price of renewable energy technologies. RETs are not viable because of their high cost production (Painuly, 2001). For this reason, RE have encountered many difficulties to compete with fuel fossil energy during the last decades. It greatly affects the cost and end-user's affordability in Bangladesh. Indeed, this challenge should be overcome by government subsidies, tax breaks and feed in tariffs. To surmount these barriers, entrepreneurs should rethink their business models taking into consideration the end-user's ability to afford RE. Governments have to deploy incentives, in spite of their limited resources, especially in the initial stages in order to promote the innovation and R\&D activities in that sector (Painuly, 2001). The return on an investment in renewable energy takes more time than fossil energy and its market size is not large enough which affects negatively the achievement of economies of scale. The lack of access to capital and its high cost may also affect the economic viability of entrepreneurial opportunities, which comes from renewable energy. The perceived risk is high, and then financial institutions hesitate to support the investments. They tend to prefer conventional energy rather than the clean one.

Similarly, there are many institutional, political and legal barriers to renewable energy entrepreneurship in 
Bangladesh. Painuly (2015: 81) argues that the lack of institutional mechanisms to disseminate information leads to a non-availability of information with producers as well as consumers. At the macro-economic level, instability increases risk and uncertainty for new investments. It incites investors to prefer products with low payback period. As a result, they prefer exploitation activities rather than exploration and innovation by investing in R\&D activities.

\section{Entrepreneurial Perspective of Renewable Energy}

The Energy sector of Bangladesh is highly monopolistic and controlled by public authorities. The established firms are large and they tend to prefer to market their existing profitable technology rather than promoting RETs. Given subsidies to conventional energy, especially fossil fuels, have affected the development of renewable energy and its competitiveness. According to Power Division, 2014, the fossil fuel subsidies budget in Bangladesh more than renewable energy in 2015.

If the renewable energy market was large, costs would be driven down and competitiveness would increase. Renewable energy is also negatively affected by the competitiveness of conventional energy. This is also due to the lack of entrepreneurs, small businesses and skilled workers who are able to promote and expand market of RETs in Bangladesh (Bridle et al., 2014). The Market is not perfect in reality because externalities such as pollution, climate change costs and health costs are not considered. It is also imperfect because of the lack of transparency and the lack of information and data (Leidreiter and Boselli,2015). The Bangladesh experience in renewable energy is relatively novel. That's why there is a lack of knowledge and data and thereby the ability of entrepreneurs to evaluate the entrepreneurial potentialities of the strategy of renewable energy remains immature. The lack of transparency affects the decision-making process and the interests behind these decisions. Due to the lack of knowledge, entrepreneurs cannot understand the real potential of renewable energy, how it works, its main benefits and challenges (Leidreiter and Boselli, 2015).

\section{Renewable Energy Technology Absorptive Capacity in Bangladesh}

Several experiences around the world demonstrate that the culture and education systems influence real income through imbedding resources in people (Islam, 2015). These variables define the concept of human capital. It plays an important role in enhancing innovation and promoting research and knowledge creation in emerging sectors. It seems difficult to achieve the strategic goals with a strong lack of knowledge and understanding of the potential of RE among citizens.

To develop a sustainable innovation and research in renewable energy field, Bangladesh has established institutions and initiated many programmes and interventions. These institutions aim to promote knowledge creation, R\&D activities and innovation by networking and building collaboration among academic researchers, projects and universities in order to develop the national capacity of innovation. They are the pivot of an emerging innovation system in RE energy.

In the same way, knowledge transfer is one of the most important expectations. It can be achieved through the establishment of long-term relationships among SMEs, large companies, universities and training centers. Empirical observation shows that the involvement of international firms is perceived as a positive thing because it allows transferring skills, technology and operational experience required for local SMEs (Germanwatch, 2015). According to representatives of local SMEs, technology and knowledge transfer is a prerequisite for RE related projects to produce what is desired in terms of opportunities and benefits in the region. Nevertheless, the limited absorptive capacity of small firms may not enable significant spillover effects.

Researchers generally agree on the fact that economic and financial factors are one of the major barriers to promoting and developing entrepreneurship in renewable energy in developing countries (Painuly, 2001). Renewable opportunities are perceived as being not viable because of the high cost of renewable technology. Consequently, the most important financial resources for RETs still fully come from the Bangladesh government and from international institutions rather than from local and private banks (Whitley and Granoff, 2014).

In the Bangladesh context, there is a strong lack of experienced banks and investment funds that make them able to provide credit and support investments in RE. Moreover, the scarcity of financial resources, the difficulty to access the capital market and lack of enhancements all contribute to increase risks and uncertainty in RETs. Specifically in Bangladesh, many studies indicate that there is a lack of accessible financial support for small scale projects able to facilitate private consumers to install RE technologies. According to Painuly's results on economic and financial barriers especially the fact that RE projects become unviable because of its high payback period. Leidreiter and Boselli (2015) assume that investors tend to prefer investing in short-termism rather than long-termism. They direct their investments to large-projects with high return on investment and within a short term. These results are compatible with Germanwatch et al. (2015: 215) study in which it is mentioned that SMEs are constrained by the lack of financial resources for upfront investment in new equipment and acquiring competencies to meet the needs of the project developers. It is also argued that they lack the cash flow necessary to wait for the stipulated three months for payments from the project developer. 
In general, infrastructure capacity means the presence and the quality of existing infrastructure and manufacturing or other industrial capital. Specifically, RET infrastructure capacity refers to the extent and quality of adequate electrical grids, ancillary roads, railways, ports, and waterways. It also includes the presence and quality of existing energy technology, manufacturing or other industrial facilities (IRENA, 2013: 33).

In the conception of this capacity, researchers of this work think about the global index innovation (GII) in which we find a macro level measure and rank of countries. In this extent, GII (Cornell University et al., 2016) considers three items to evaluate the country's infrastructure: information \& communication technologies (ICT access, ICT use, government's online service, e-participation), general infrastructure (Electricity output, $\mathrm{kWh} / \mathrm{cap}$, logistics performance, Gross capital formation, \% GDP), and ecological sustainability (GDP/unit of energy use, Environmental performance, ISO 14001 environmental certificates). Infrastructure is one of the seven pillars, which form the global index. In 2016, infrastructure is the GII's pillar in which Bangladesh ranks 117 among 128 countries, advanced 12 points from last year's 129.

Nevertheless, the remote rural areas of Bangladesh region have the poor infrastructures in the country, especially the healthcare system. These areas lack basic community infrastructures and services, such as access to clean water and sufficient health care. The implementation of RE related projects delivers lots of opportunities to improve regional infrastructure like highways and roads.

\section{Conclusion}

This work has shown that the sector of renewable energy is emerging in Bangladesh. From an entrepreneurial perspective, it delivers many opportunities for new value creation. With this work, we believe that sustainable entrepreneurship will be the most important stream of research in the future in Bangladesh. This is because of the fact that the relationship between entrepreneurship and sustainability is still in emergence, more prescriptive than descriptive and optimistic. Hence, many open questions about whether and to what extent entrepreneurs have the potential for creating sustainable economic value (Hall et al. 2010: 445). The RE in emerging economies could be the sector in which these countries can develop new business models (Gabriel et al., 2016) because of its specificity and economic potential in terms of value creation, job creation, innovation, knowledge and technology transfer. While entrepreneurial opportunities depend on market imperfections, governance, the vision of policy makers and the relative ease of doing business, a factor such as absorptive capacity is considered as critical when promoting entrepreneurship in RE. It includes the entrepreneur's or region's abilities to acquire, learn, and exploit external knowledge.

Our article is focused in the Bangladesh strategy of renewable energy from an entrepreneurial perspective. Bangladesh's promising interest in renewable energy is viewed through the lens of entrepreneurship considering the market imperfections in the Bangladesh context and the RETs absorptive capacity. The results have indicated that there is a great potential in terms of value creation and entrepreneurship in RE in Bangladesh. However, barriers related to contextual variables such as legal and policy factors could obstruct the achievement of this potential. In Bangladesh, as well as in other developing countries, the emergence of business models for renewable energy fails due to corruption and deficiencies in legal frameworks. In the Bangladesh context, the regularity and policy frameworks must encourage the involvement of small entrepreneurs in the implementation of the national strategy to achieve its goals. Small firms in the renewable energy sector are still managed by first generation entrepreneurs lacking abilities to realize economies of scale.

\section{Reference}

Ahammed, F. and Taufiq, D.A. (2015). Case Study: Applications of Solar PV on Rural Development in Bangladesh. Journal of Rural Community Development 3, 93-103.

A. K. Azad (2011), “A Review on Renewable PowerSources: Prospects of Bangladesh and Scotland, "EBook, St. Andrew's University, Scotland, UK.Available: http://pdfmio.com/download/renewablepower

Bridle, R., Kiston, L., Wooders, P. (2014), Fossil fuel subsidies: a barrier to renewable energy in5 Middle East and North African countries, IISD and GSA publication, http://www.iisd.org/gsi/sites/default/files/fossilfuel-subsidies-renewable-energy-middle-east-north-african-countri\%20\%20\%20.pdf, Accessed August, 25th, 2016.

Barua, C.D., Urmee, T.P., Kumar, S., \&amp; Bhattacharya S. (2016). A photovoltaic solar home system dissemination model. Progress in Photovoltaic Research and Applications, 9, 313-322.

Brown and C. Hendry, "Public demonstration projects and field trials: Accelerating commercialization of sustainable technology in solarphotovoltaics," Energy Policy, vol. 37, no. 7, pp.2560-2573, Jul. 2009.

British Petroleum official website under renewable energy, solar energy, (2011, March). URL:http:/www.bp.com/sectiongenericarticle.do?categoryId=9023789\&contentId=7044135

Cohen, B. and Winn, M.I. (2007), Market imperfections, opportunity and sustainable entrepreneurship, Journal of Business Venturing, 22, pp. 29-49.

Cornell University, INSEAD, and WIPO (2016), The Global Innovation Index 2016: Winning withGlobal 
Innovation, Ithaca, Fontainebleau, and Geneva.

Dean, T.J. and McMullen, J.S. (2007), Toward a theory of sustainable entrepreneurship: Reducing environmental degradation through entrepreneurial action, Journal of Business Venturing, 22,pp. 50-76.

Engelken, M., Römer, B., Drescher, M. and Welpe, I. (2016), Comparing drivers, barriers, and opportunities for business models for renewable energies: a review, Renewable and Sustainable Energy Reviews, 60, pp. 795-809

Gabriel, C.A. (2016), What is challenging renewable energy entrepreneurs in developing countries, Renewable and Sustainable Energy Reviews, 64, pp. 362-371.

Germanwatch and Wuppertal Institute (2015), Energy and development: exploring the local livelihood dimension, Final report to the GermanFederal.

Hall, K.J., Daneke, A.G. et Lenox, M.J. (2010), Sustainable devlopement and entrepreneurship :past contributions and future directions, Journal of business Venturing, 25, pp. 439-448.Holcombe, R.G. (2003), The Origins of Entrepreneurial Opportunities, The Review of AustrianEconomics, 16(1), pp. 25-43.

Hasan, M. R., Arifin, K., Rahman, A., \& Azad, A. (2011). Design, implementation and performance of a controller for uninterruptible solar hot water system. Paper presented at the 2011 IEEE 18th International Conference on Industrial Engineering and Engineering Management, IE and EM 2011, (PART 1) 584-588. doi:10.1109/IEEM.2011.6035226

IDCOL Renewable Energy Projects, Bangladesh, (2011, March). URL: http://www.idcol.org/energyProject.php

IRENA, (The International Renewable Energy Agency) (2013), Renewable energy innovation policy: success criteria and strategies, IRENA Working Paper, https://www.irena.org/DocumentDownloads/Publications/Renewable_Energy_Innovation_Policy.pdf, Accessed onspetember 3rd, 2018.

Islam, A.K.M.S and Islam,M. (2015).Status of Renewable Technologies in Bangladesh. Journal of ISESCO Science and Technology Vision, 1, 51-60.

Islam, IDCOL, Renewable Energy Development in Bangladesh, presented at Madrid, Spain, Oct. 2009.

Leidreider, A., and Boselli, F. (2015), 100\% renewable energy boosting development in Morocoo, World Future Council, http://africa-renewable-energy-forum.com/fr/webfm_send/1606,Accessed on September 3rd, 2018.

Moury, and R Ahshan, "A feasibility study of anon-grid solar home system in Bangladesh," Proc. of the IEEE ICDRET, Dhaka, Dec. 2009.

M. S. Kaiser, M. A. Rahman, M. M. Rahman, and S.A. Sharna, "Wind energy assessment for the coastalpart of Bangladesh," Journal of Engineering andApplied Sciences, vol. 1, no. 2, pp. 87-92, 2006.

Khan, M.J. \& Iqbal, M.T. \& Mahboob, S., 2014. "A wind map of Bangladesh," Renewable Energy, Elsevier, vol. 29(5), pages 643-660.

M. A. H. Mondal, "Implications of renewable energy technologies in the Bangladesh power sector: Long term planning strategies," Ph.D. dissertation, Dept.of Ecology and Natural Resources Management ,ZEF, University of Bonn, Germany, Jul. 2010.

Martinot, E., Cabraal, A., and Mathur, S. (2001), World Bank/GEF solar home system projects: experiences and lessons learned 1993-2000. Renew Sustain Energy Rev, 5, pp. 39-57.

Painuly, J.P. (2001), Barriers to renewable energy penetration ; a framework for analysis, Renewable Energy, 24, pp. 73-89.

Power Division, 2014. Alokito Bangladesh. "Success in power sector during five years (2009-2014)".Power Division, Ministry of Power Energy Mineral Resources, the Peoplee s Republic of Bangladesh.

PSMP (Power System Master Plan). 2010. Bangladesh 2030 Vision, Long Term Power Development Strategy. TEPCO, Japan and Power Division, Ministry of Power Energy and Mineral Resources.

Shane, S. (2004), A general theory of entrepreneurship: the individual-opportunity nexus, Edward Elgar Publishing Incorporated, Northampton.

Stel, N. (2013), Entrepreneurs in the dark: the impact of fragile and hybrid governance on Lebanese entrepreneurship - a case-study of the electricity sector, Journal of Developmental Entrepreneurship, 18 (3), pp.1-17.

Renewable energy projects, IDCOL solar energy program, (2011, March). URL: http://www.idcol.org/prjshsm2004.php

Renewable energy technology characterizations,TR-109496, Topical Report, U.S. Department of Energy, and Electric Power Research Institute(EPRI), Dec. 2013.

Renewable energy information network, Solar interventions in Bangladesh (2011, March). URL:http://www.lged-rein.org/bpdb.php

Renewable Energy Policy of Bangladesh, Power Division, Ministry of Power, Energy and Mineral Resources, Bangladesh, Nov. 2008.

Urban, B. (2013), Influence of the institutional environment on entrepreneurial intentions in anemerging economy, Entrepreneurship and Innovation,14 (3), pp. 179-191. 
Venkataraman, S. (2010), The distinctive domain of entrepreneurship research: an editor's perspective, in Katz, J. and Brockhaus, J. (Eds.), Advances in Entrepreneurship, Firm Emergence, and Growth, JAI Press, Greenwich, CT.

Whitely, S., Granoff, D. (2014), The Moroccan Agency for Solar Energy and the Moroccan SolarPlan, Green Growth Best practice, http://www.ggbp.org/case-studies/morocco/moroccanagency-solar-energy-andmoroccan-solar-plan, Accessed on September, 3rd 2018. 